\title{
Innovative strategies for the reception of asylum seekers and refugees in European cities: multi-level governance, multi-sector urban networks and local engagement
}

\author{
Caroline Oliver $^{1 *}$ (D), Rianne Dekker ${ }^{2}$, Karin Geuijen ${ }^{2}$ and Jacqueline Broadhead ${ }^{3}$
}

\footnotetext{
* Correspondence: c.oliver@ucl.ac.uk 1 Institute of Education, University College London, 20 Bedford Way, Bloomsbury, WC1H OAL, London, UK

Full list of author information is available at the end of the article
}

\begin{abstract}
Cities are taking a prominent role in solving global challenges, with a 'new localism' inviting a reorientation of power from nation-states downwards, outwards and globally. This special issue explores this phenomenon through extending the existing analyses of multi-level governance and the 'local turn' to the underexplored area of asylum seeker and refugee reception in European cities. The special issue draws on research in European cities where new strategies were piloted especially in the wake of 'the refugee crisis' from 2015, consolidating the 'local turn' evident in immigration and integration policy-making. The collection is in two parts: the first part explores innovation in local governance of asylum seeker reception. Here, case studies demonstrate how cities responded through forging new alliances both vertically and (especially) horizontally in networks within and between cities. The second part explores innovation in practice, analysing novel initiatives premised on local engagement and inclusivity of newcomers within the social fabric of the city. This editorial paper draws out the wider lessons of efforts from this comparative exploration of attempts to rethink asylum seeker and refugee reception at the local level.
\end{abstract}

Keywords: Asylum seekers, Refugees, Reception, Europe, Multi-level governance, Networks, Innovation, Urban, Cities, Migration

The question of how to receive asylum seekers is of the highest importance for urban local governments, a challenge among the most pressing issues they face. Between 2014 and 2016, there was a significant increase in numbers of displaced persons seeking asylum in Europe, including over 1.2 million asylum applications in 2015 (Eurostat 2020). Local authorities across European towns and cities faced practical challenges in rapidly adjusting to a scenario of people arriving and requiring emergency accommodation. This provoked challenges for community cohesion, as public opinion has become increasingly polarized between anti-immigrant sentiment and a more welcoming, humanitarian disposition (Rea et al. 2019). The special issue of Comparative Migration Studies brings together research examining how a range of European cities responded in innovative ways to the issue. It presents six case-studies, including cities in both

(c) The Author(s). 2020 Open Access This article is licensed under a Creative Commons Attribution 4.0 International License, which permits use, sharing, adaptation, distribution and reproduction in any medium or format, as long as you give appropriate credit to the original author(s) and the source, provide a link to the Creative Commons licence, and indicate if changes were made. The images or other third party material in this article are included in the article's Creative Commons licence, unless indicated otherwise in a credit line to the material. If material is not included in the article's Creative Commons licence and your intended use is not permitted by statutory regulation or exceeds the permitted use, you will need to obtain permission directly from the copyright holder. To view a copy of this licence, visit http://creativecommons.org/licenses/by/4.0/. 
(historically) transit countries in the Mediterranean region and those with more established histories of immigration in North-Western Europe. The contributions invite reflections on the extent to which local innovation is possible within broader frameworks of regional, national and European policy.

Asylum seeker reception is an example of a complex global issue that manifests itself locally. Such issues drive what Katz and Nowak (2018) describe as the 'new localism', referring to radical shifts in the location of power: downwards from nation-states to cities, horizontally from national governments to networks and globally to transnational networks (Marks and Hooghe 2004; Barber 2013). Pannizon and van Riemsdijk (2019) suggest that the European refugee 'crisis' heralded a reorganization of power constellations between local, regional, national and supranational governance. Migration policy-making at the European level saw shifts in both the interactions between the supranational and intergovernmental realms as well as intergovernmental cooperation on migration issues (ibid., Slominski and Trauner 2018). Yet it instigated to a shift of power downwards and horizontally, especially as local municipalities were left to manage the consequences of incapacity at the EU and national level to quickly and adequately respond to the urgency of asylum seeker reception (Caponio 2019; Agustín and Jørgensen 2019).

Migration research had already noted this downward shift through attention to the 'local turn' in migration policy, referring to the trend of cities taking a more prominent role in the broader framework of multi-level governance [MLG] of migration (Caponio and Borkert 2010; Scholten 2013; Dekker et al. 2015; Scholten and Penninx 2016; Zapata-Barrero et al. 2017). As Garcés-Mascareñas and Gebhardt (2020, p. 3) note, 'cities become particularly relevant whenever they go beyond the role of simple passive implementers and actively interact with national or regional policies'. Recognizing the critical role of cities is important too to temper the 'methodological nationalism' that privileges the nation-state in migration research; more understanding is required of migrants relationships with the cities in which they live, including their active role in citymaking (Çağlar and Glick Schiller 2018). While MLG is well explored in relation to broader migration integration processes, as well as to undocumented migrants (Spencer 2018) this special issue adds to that corpus of knowledge by understanding how the local turn manifests in relation to asylum seeker reception, complementing the collection by Glorius and Doomernik (2020) on this theme.

Paying attention to city-level innovation should not suggest that this is necessarily a common practice. Indeed, evidence points to widespread convergence in reception approaches across European cities, reflecting local governments' limited role in decisionmaking as relevant policies are shaped at the national and supranational level (Kreichauf 2018; Glorius and Doomernik 2020). Some evidence even suggests that national governments are also aiming to regain power over local integration policies and exert greater control and influence at the local level (Campomori and Ambrosini 2020; Emilsson 2015). However, the case studies point to an important counter-trend where local actors assume the role of innovators and policy entrepreneurs, sometimes developing policies completely apart from national policy, a process described as 'decoupling' (Scholten and Penninx 2016). The innovations often build on civic and political traditions which, through the contributions of individuals, voluntary, faith groups, media and police, cultivate an 'urban citizenship' as an antidote to national policies (Hintjens and Pouri 2014, see Oomen 2019a). This is evident in cities developing their own 
responses in wider policy domains, such as in environmental or housing policies (e.g. in Barcelona's curbing of the tourist rental market or London's Ultra Low Emission Zone aiming to improve air quality) as well as those more specifically in the migration and integration sector. These include examples such as New York's IDNYC programme, to provide identification documents for all city residents, including irregular migrants, Dutch cities' development of a 'Bed, Bath and Bread' provision for irregular migrants in contravention of national policy frameworks, and Liverpool's decision to allow people access to homeless shelters regardless of immigration status.

To understand this specific type of urban innovation in the field of asylum seeker and refugee reception, we adopt Sørensen \& Torfing's (2011, p. 8) widely accepted definition of collaborative public innovation as, 'an intentional proactive process that involves the generation, practical adoption and spread of new and creative ideas, which aim to produce a qualitative change in a specific context'. This collection considers how cities -as contexts and referring to the multi-sector urban networks of local actors therein- were able to seize a moment of opportunity to disrupt and innovate asylum policies and practices. In presenting some of these innovations, our aim is not to provide an overview of practices, since there are many other emerging developments which we cannot include. Rather the collection aims to examine case studies of cities in depth, to understand the reasons for and mechanisms involved in development, as well as to understand their dynamics and emerging outcomes. To do so, the collection considers innovation in this field in two ways.

First, the special issue explores case studies of innovations in governance: the emerging organizational arrangements, alliances and dynamics of sharing, or contesting, power around the issue of asylum seeker reception. Innovation in this sphere occurs where networks of different actors meet in new configurations to fill gaps and change local practice, including through collections of local, national, regional and international partners in horizontal, sub and transnational networks. These actors can disrupt or even partially exit from national state-run hierarchies, become part of multiscalar, regional and global networks and assert the power of subnational jurisdictions (Sassen 2012 and see Oomen 2019b). Funding from the European Union and other sources such as independent philanthropy can be an incentive for new networks to form and for their legitimacy to grow - as some of the case studies show; they may be radical, combative or unfold in more limited and constrained ways.

The second form of innovation refers to innovation in local practices: the material arrangements, initiatives and schemes put in place locally to receive asylum seekers into the city. As much as a local turn, the examples indicate 'a turn to the local', as city authorities engage specific local actors and neighbourhoods to co-create and try out new and different ways of 'doing' rather than 'giving' reception. Poppelaars and Scholten (2008) point out that local levels of governance tend to prioritize pragmatic approaches to integration over the ideological drivers of national approaches to the issue. The cases include here indicate this is true, yet they also highlight a growing confidence in the local level at developing responses and building alliances founded on different values and goals (Katz and Nowak 2018, see also Oomen 2019a). While it cannot be assumed that local policy formation is always inclusionary (see Ambrosini 2013) and there can be a confirmation bias towards inclusionary cities in this field (Caponio 2019) nevertheless, these types of initiatives often show more concern for humanitarian logics. They 
embrace values of diversity, prioritize inclusivity and claim responsibilities towards the new urban inhabitants as 'newcomers' and 'urban citizens' rather than more stigmatized and ideologically loaded notions of asylum seekers or refugees (Oomen 2019a). According to Agustín and Jørgensen (2019) many new solidarity movements emerging also indicates a new kind of 'cosmopolitanism from below'. New frames are developing at the local level, which draw on the different role and competencies of local governance in focusing on such notions of inclusive community rather than an exclusionary frame (Broadhead 2020).

Urban initiatives also demonstrate a parallel concern for existing residents, recognizing the impacts of asylum seeking on community cohesion. Local community objections may be founded on a sense of economic competition, cultural distance and security concerns (Zorlu 2017). Yet recognizing these concerns can inform the design of reception models, and also inform sensitive communication around reception. Several initiatives in this collection did so by reframing a prevailing local notion of refugees as a 'burden' and sought to bridge social distance between existing inhabitants and newcomers (Zill et al. 2020; Oliver et al. 2020). This embraces a notion of cities as 'strategic frontier zones', where cities are sites in which alternative, more inclusive intercultural norms of migrant reception can be forged (Sassen 2012; Zapata-Barrero 2019). Attention to the urban should not overlook that especially through dispersal policies, reception also often occurs in rural areas and smaller towns, and innovation can also occur there (Whyte et al. 2019; Bock 2018; Caponio 2019). Assuming that urban areas hold the monopoly on innovation risks replicating and reinforcing divides (Jennings and Stoker 2016). Nevertheless, scholars are acknowledging the increasing urban articulation of global issues (Sassen 2012) recognising there is often more capacity, opportunities for mobilization and political will in large cities to bring about change (Caponio 2019). As Sassen (2012) poses, while cities can be spaces of exclusion and sites of operation for global corporate capital, they are also hybrid spaces that possess the capacity for inhabitants to develop alternative norms, forge new identities and overcome divisions and borders.

The special issue examines how experiments in asylum seeker reception aim to harness this transformative potential of cities. It critically examines how they fare over time, especially when they chafe against nationally managed and centralised systems of asylum reception. The particular questions posed are summarized as follows:

1. What forms of alternative and innovative responses to asylum seeker and refugee reception can be seen emerging at the local level in European cities?

2. What are the dynamics of multi-level and multi-sector governance in asylum seeker reception? In particular what role do horizontal alliances and other sub or transnational networks have and how do these interact with national governments?

3. What can be learned from the empirical study of specific local innovations for asylum seeker reception founded on principles of inclusivity? What is their potential for addressing problems in reception and forging understanding between asylum seekers and existing city inhabitants?

In the following discussion, the argument is first made for why innovation is emerging, and why therefore a collection such as this, is significant and timely. This is 
followed by assessment of the individual contributions to the Special Issue, as related to the questions we pose above.

\section{Rationale: the need for and potentials of innovation in asylum seeker reception}

Asylum seeker reception poses a major challenge to multi-level migration governance. As a complex, or 'wicked' global policy issue, like other areas of immigrant reception and integration, it is an intractable policy problem that defies a clear solution, with different views at different levels on how to approach the issue, or indeed what is the issue (Boswell 2008; Scholten 2013; Geuijen et al. 2017). Certainly, migration is a field where actors' views at national and local level can be highly divergent (Spencer 2018; Ambrosini 2013; Scholten 2013; Scholten and Penninx 2016).

This disconnect stems from the fact that asylum is a competence managed by national governments, where cities are subject to top down decision-making and the imposition of centralised policies. Localities, by contrast have a major role in the practical management of asylum seeker reception, with only limited input into decision-making (Glorius and Doomernik 2020). There are also divergent values, logics and objectives for asylum seeker reception. At national level, the goal is primarily to guard the integrity of national borders, an objective governed through laws, rules and obligations (Barber 2013). As Darling (2014, p. 77) explains, a 'classificatory impulse of the 'domopolitics' of asylum' drives the development of a regime to secure, keep order and maintain an image of the nation. This is achieved through largely administrative and rational processes of categorising, accommodating, dispersing and detaining asylum seekers to determine those 'worthy' or 'bogus' in placing a claim on state resources (Darling 2014). While status determination occurs, reception is provided at a most basic level, at the lowest costs. This both discourages people from arriving and staying and simultaneously displays a government's 'toughness' on immigration to its public (Mayblin and James 2019).

A different set of concerns manifest at the local level, where authorities are tasked with practically managing the effects of sudden migratory flows on the social fabric of the city. Hostility and public protests about the local provision of accommodation for asylum seekers can threaten the social order in the city, especially when reception facilities are located in marginalized neighbourhoods for reasons of cost and efficiency (Bock 2018; Oliver et al. 2020). Fears are exacerbated too by reception occurring in 'camp-like' structures across European cities, which share socio-spatial characteristics that limit connections between asylum seekers and the localities in which they are placed (Kreichauf 2018). Nationally imposed asylum conditions forbid asylum seekers from participation in local economies, some use curfews to restrict movement. Such social and spatial isolation can help depoliticize the issue, by 'distanc [ing] those seeking asylum from the political and the public gaze' (Darling 2014, p. 77).

Practical concerns are also met with moral concerns for the treatment of asylum seekers at the local level. Although the EU's Common European Asylum System (CEAS) through the Directive on Reception Conditions sets minimal standards on how asylum seekers are treated while their application is being processed, Glorius and Doomernik (2020) point out that there is, in practice, a great deal of variation in provision. Austerity measures in public spending coupled with welfare chauvinism has meant that 
reception conditions have been deteriorating. Critics of the CEAS argue that rather than safeguard standards, it acts more like a 'race to the bottom', in which countries already maintaining good reception standards could be deteriorated and where bad, countries could opt out anyway (Mayblin 2016). As Mayblin and James (2019, p. 377) note, support for asylum seekers is not electorally popular, so at national levels, there is even a 'political disincentive to ensure support levels are adequate'. This deterioration in standards is evident across a range of European countries. Italy's former populist government led by League and the Five Star Movement in 2018 installed a more restrictive system of asylum seeker reception, delivering emergency reception of just 'bed and bread', and removing funding for other services such as legal help and language courses (Campomori and Ambrosini 2020). In the UK, the outsourcing of asylum to centralized private providers has worsened conditions of reception and limited local authority control further (Darling 2016). Under the last contracting round, the government watchdog sought to recover funds of $£ 7 \mathrm{~m}$ from providers because of poor performance, with evidence to the review focusing on 'poor property standards,' including 'frequent references to defects, damp, dirt and vermin' (Independent Chief Inspector of Borders and Immigration (ICIBI) 2018, p. 14).

Such minimal standards create problems of community cohesion, and local authorities must also mitigate the longer-term consequences of asylum reception, including losses in skills and wellbeing generated during often protracted asylum processes (ibid.). Refugees experience deterioration in skills and networks through periods of inactivity and ultimately lower rates of labour market participation and higher unemployment than other migrants (Bakker et al. 2014; Kone et al. 2019). They also experience downward mobility into low skilled, low status, low paid and insecure jobs (Bloch 2008). Existing difficulties in converting human capital are worsened due to the loss and deterioration of skills while waiting and being unable to work, as well as through the inhibited possibilities to expand asylum seekers' already limited social capital within reception facilities (De Vroome and van Tubergen 2010). Reception has been shown to have damaging health and psychological effects, compounding previous trauma and aggravating asylum seekers' mental health problems as they experience their lives in limbo and 'on hold' because of the forced inactivity (Li et al. 2016; Miller and Rasmussen 2017). Many local governments are recognising that enabling earlier stage labour market participation and social integration would likely pay dividends in reducing risks of creating an excluded urban population (see Bakker et al. 2014).

Such contradictory concerns of national and local levels of government can sow the seed of contestation in governance arrangements and fuel a desire for different solutions locally. The introduction now turns to consider alternatives, focusing on six case studies, which overall provide insight into innovative responses to asylum seeker and refugee reception emerging in and across European cities (question 1).

\section{Case studies in local innovation}

Innovation in governance arrangements: network-building, conflict and cooperation

The first three contributions to the collection particularly explore different governance arrangements emerging at local level (question 2). Scholten and Penninx (2016) identified several different types of migration governance arrangement between national and 
local levels, including (1) top-down, or 'centralist', (2) bottom-up, or 'localist', (3) dehierarchised or 'multi-level' and (4) decoupled. These case studies point to an increasing development of bottom-up and decoupled governance in this field. This is especially through alliances developed within and between cities.

The first two articles explore multi-level governance from the perspective of city authorities in Spain (Barcelona) and Italy (multiple cities). Both countries are the first points of entry for asylum seekers in Europe, and responses have developed rapidly. Until the current decade they have perceived themselves mainly to be countries of transit rather than reception, given that until then, numbers of asylum seekers officially recorded were few, and arrangements little developed. The contribution by GarcésMascareñas and Gebhardt (2020) focuses on how, during recent years, Barcelona has modelled itself however as 'a city of refuge'. They show how policy entrepreneurs are developing bottom up governance and 'municipalist' philosophy in the face of a heavily centralized, but increasingly dysfunctional national approach to asylum seeker reception. Key to this has been heavy investment of the city's own resources into reception policies, as well as political arguments for change, drawing strength from coalitions made with other cities of refuge nationally, and with 'Solidarity Cities' across Europe. These alliances have translated into attempts to influence cities' rights to secure future funding, including European funds managed at the national level (Asylum and Migration Funds) and those related to the European Urban Agenda. Arguably this has led to a 'wider shift in favour of cities' in the next generation of integration funding (GarcésMascareñas and Gebhardt 2020).

Francesca Campomori's and Maurizio Ambrosini's contribution (2020) explores dynamics across regions and cities in Italy, showing how mobilizing for alternative approaches are occurring in the face of 'a renewed national turn' in Italy. The contribution shows the growing significance of horizontal multi-sector alliances in this policy field, whereby asylum seeking is a process managed not solely by national and local political authorities and NGOs. Instead it now involves a much wider group of actors, including migrants themselves, pro-immigrant actors and social movements, and including xenophobic movements too. They argue that most studies of MLG in relation to migration pay lesser attention to this horizontal dimension, favouring attention on the multi-level or vertical aspects of MLG. In addressing this deficit, they describe local policies of reception as 'a playing field' where a much broader range of actors, both state and non-state come together. This is confirmed within other accounts later in the collection (e.g. Oliver et al. 2020), where innovation comes from multi-sector networks including public-private partnerships, involving actors from local businesses and social enterprises. These networks can also include educational institutions, both as providers of services and involved in research, evaluation and knowledge exchange (see also Broadhead 2020).

Both contributions also expose the dynamics and understandings between different actors at both different levels of governance and within multi-sector alliances. As Campomori and Ambrosini (2020) assert, crucial here is a recognition of MLG less as a 'negotiated order', but a process marked by conflict. Campomori and Ambrosini favour the concept of 'battleground' as a more appropriate metaphor to characterise the (often neglected) interplay between vertical and horizontal spaces. Friction and tension is also present in the palpable and growing anger which fuels confidence among local 
coalitions to resist implementation or remedy the effects of national systems, as well as increasing demand at local level for funds to support those actions (see also Garcés-Mascareñas and Gebhardt 2020). Campomori and Ambrosini helpfully analyse how a range of dynamics can characterize the interplay between public powers and civil society organizations. These stances include: closure to civil society activism; tolerance; immigrant activism vs anti-immigrant mobilization; and cooperation. Nevertheless, within multi-sector alliances, while conflict may be a defining characteristic, we see that other forms of cooperation emerge where a shared perspective on this topic transcend other important differences. Thus in Spain, Garcés-Mascareñas and Gebhardt show how cities from different political colours were able to unite under the same cause.

City to city cooperation is particularly prominent with the third case study in the collection: Jacqueline Broadhead's (2020) analysis of an emerging UK city network. This provides an example of how under even constrained conditions of highly centralised national policy on asylum and resettlement and privatised asylum seeker accommodation, city governments have collaborated in order to develop more assertive leadership. Broadhead examines a newly emerging city network informed by knowledge exchange from the University of Oxford and a transnational learning exchange. This fledgling network helped to bring cities together, inspiring and informing local practice. Broadhead's analysis identifies some of the key strategies for inclusion identified at city level. These include first, the reframing of the migration issue towards a 'newcomer' frame. Here, asylum seekers are responded to less as a category requiring treatment, and as part of a broader group of people arriving in a city. Second, is the development of citybranding, whereby the cities develop place-based narratives of inclusion. Key to embedding a broader notion of reception is strategic leadership, exemplifying the importance of key local political representatives as influencers to champion alternatives and resist the national model. In Broadhead's case-study, we see the recent introduction of a new Deputy Mayor responsible for social integration in London. In Barcelona, it is the mayor Ada Colau who called for a network of welcoming cities to avoid the 'war on life' that was playing out in asylum seeker reception.

Finally, several of the cases underline how city to city networks are proving an important force in mobilization (Caponio 2019, see also Oomen 2019b). Often they developed with a function to exchange ideas and learn from each others' experiences of local integration policies (e.g. in the 'Cities for Local Integration Policies' (CLIP) which began in 2006 as an initiative of policy makers to network 25 European cities). Yet these alliances have increasingly developed into numerous and sometimes large regional and transnational cooperative networks, such as Eurocities, Intercultural Cities networks, the Global Parliament of Mayors and the recently founded Mayors Migration Council (Oomen 2019b). The alliances draw benefits from exchanging information, sharing experiences and developing strategies collaboratively (Barber 2013; Oomen 2019b; Garcés-Mascareñas and Gebhardt 2020). As Oomen (2019b) shows however, there is often great power in 'teaming up', not only to share experiences, but develop alternative narratives. Collective mobilisation is more powerful in contesting nationally restrictive arguments and can also help influence the global legal framework, as 150 mayors of cities were able to do in contributing a city perspective to the 2018 Global Compact on Refugees and Migrants (ibid.) 
Innovations in practices: a turn to the local for social inclusion

Moving now to the second master-theme of the collection, we reflect on practical experiments undertaken at city-level. All provided architectures, mechanisms and activities to generate social connections and provide a more inclusive form of reception for asylum seekers and refugees. We begin with Mahieu and Van Caudenberg (2020) analysis of an urban programme that involved young unaccompanied refugees cohabitation with young local citizens in small-scale collective housing units in Antwerp. Their article considers the opportunities this provided for social support and mutual learning, reflecting on the wider role that intercultural living can bring for newcomer integration. This is followed by Oliver, Geuijen and Dekker's et al.'s (2020) account of the Utrecht Refugee Launchpad (URLP), a co-housing project that attempted to facilitate social contact between a group of young, local tenants and asylum seekers housed in the same complex. We end the collection with Zill Spierings \& Van Liempt's (2020) Lefebvrian exploration of an alternative space of asylum seeker reception emerging from civil society organizations and third sector activism, the Grandhotel Cosmopolis in Augsburg, Germany. Part-hotel, part- asylum seeker centre, its café, restaurant and artistic space provided sites of encounter between local residents, tourists and asylum seekers, while its playful imaginaries of the space of asylum reception as a 'grandhotel', evokes images of encounter and intercultural exchange.

All three examples show how local consensus is an important aspect of innovative projects. While existing scholarship has identified policy making as taking a 'local turn', these case studies demonstrate a 'turn to the local'. By this we mean that the innovations were founded on a pragmatic recognition that reception occurs in real neighbourhoods with real people. Not only is power located downwards but so too is responsibility for newcomers' experiences within the city as part of their urban citizenry. For example in Utrecht, the local government officials responsible for URLP, or 'Plan Einstein' as the initiative was colloquially known, referred to asylum seekers living in the city as 'ours' (fieldnotes from study by Oliver, Dekker and Geuijen 2019). By 'turning to the local', innovations strategically used pre-existing and newly emerging local horizontal networks, especially between local government and civil society. However, equally, two of the initiatives were also able to seek support vertically, by exploiting a rare opportunity of European funding being directly channelled to cities through the Urban Innovative Actions scheme (https://www.uia-initiative.eu/en). Such funding allows cities to bypass the national governments and pursue their own agendas (see also Garcés-Mascareñas and Gebhardt 2020). These finances were invaluable not only for allowing adequate resources to fully support the investment, but they also lent legitimacy locally and nationally to the experiments. Ironically, such funding may even provide a politically acceptable means for national governments to permit cities like Utrecht to experiment locally in ways that would be more difficult on a national scale (Geuijen, Oliver and Dekker 2020).

However, as some of the examples show, there can be implications of projects being framed as 'experimental', and 'new'. Innovation, by its very nature is unlikely to get everything right at first and rather implies learning through experimentation. This sits somewhat at odds with the high-risk and public nature of the ventures examined in this collection, whereby the innovations attracted high public interest. Yet as Zill et al. (2020) show, a positive media spin on these 'model projects' can take a life of its own. 
Despite local media reporting presenting the Grandhotel Cosmopolis as experimental, the media construction at the national level was framed in 'utopian' terms. Their analysis shows that this reduced the innovation to a unique and 'modern fairytale' rather than any real, plausible alternative, or site of potential critique to the status quo nationally. The media depictions were also far removed from the reality of those living nearby, where reactions were informed by direct experience.

The strongest contribution of these three articles is however to the final question of our special issue (3). Through detailed empirical study, they shed light on cities' attempts to forge greater intercultural understanding between asylum seekers and locals, based on an assumption that proximate living would create meaningful encounters. This was developed in different way across the innovations. In Antwerp, the concept of 'organized befriending' was embedded into communal living, where refugees were matched with young buddies through a carefully considered process by professionals. In Utrecht, cohousing and shared space for joint use by asylum seekers and tenants, alongside a wider co-learning educational programme open to both asylum seekers and locals was adopted. In Augsburg, the Grandhotel Cosmopolis project's ambition for more open asylum reception stretched out to the wider community, as the reception space was designed as an open space for spontaneous encounter. It sought too to engage with both the imagined geographies of asylum and lived experiences, recognising that asylum seekers understood in mental images and 'representational space', as well as through physical engagement in 'lived spaces'. In the final part of this editorial introduction, we consider then to what extent did the noble ideas behind these practical experiments live up to their transformative potential in dismantling categories of 'us' and 'them'?

All three contributions offer some evidence that intervening in this type of local connection can provoke some kind of meaningful encounter. They confirm academic research which shows the positive benefits of social contact and encounter for enhancing intercultural understanding (e.g. in Allport's (1954) contact hypothesis). Mahieu and Van Caudenberg (2020) show that befriending enabled instrumental social support, crucially by lowering the threshold for refugees asking for help and providing opportunity for informal learning in situations of daily living. The simple notion of just 'having someone around' offered them a welcome distraction from their past and present challenges. In Utrecht, asylum seekers similarly valued the opportunity to just be around other Dutch people, with tenants offering a glimpse into the realities of a regular life in Utrecht. Zill et al. (2020) show that the space of asylum accommodation is physically and socially produced, created not only through media representations, but also through direct experience of asylum seeker spaces.

Nevertheless, all the contributions show that developing intercultural encounters and shifting imagined representations of this group is not easy and the assumptions and expectations embedded within such innovations should be carefully considered. In Antwerp, contact was developed in a top-down manner, through the professionals selecting and matching buddies to work on a one-to-one basis with refugees in gender-mixed pairs. Mahieu and Van Caudenberg (2020) show that expectations of asylum seekers and buddies sometimes differed and that intimate co-housing arrangements sometimes created misunderstandings along cultural and gendered dividing lines. In Utrecht, social contact fluctuated over the course of the project and encounters varied in ease and intensity, and at times, became awkward and difficult. Oliver et al. (2020) show that it 
was influenced heavily by conditions and contexts outside the project. Contact worked best when numbers were fewer, ratios equal (around 40:40), people shared similar characteristics (of age and education) and there was enough time for relationships to develop. However, these conditions were not easily met within the constraints of national asylum management where people were moved regularly, often far from the city, directly contravening local policy. Similarly, in Augsburg, we see that despite being able to 'walk in', local people's reactions were still heavily influenced by external, mediatized constructions of asylum seekers as either criminals or victims. Being close had only a limited effect on attitudes (Zill et al. 2020).

Developing intercultural encounters and shifting imagined representations were also affected by spatial arrangements. In all three cities, new reception facilities were quickly adapted to meet housing needs: In Antwerp, the collective housing was provided in a range of apartments, housing and a site built for the project including 16 two-bedroom modular units. In Utrecht, the site was a refurbished office building. In Augsburg the Grandhotel was a renovated former home for the elderly. All accounts demonstrated that physical locations and material conditions of asylum reception matter. In Antwerp, the opportunity to live together provided opportunities for pairs to exchange small gestures of help and share household items or lend furniture. However, these could be loaded exchanges, due to material inequalities between the groups. In Utrecht, tenants and asylum seekers lived close, but separately, yet notions of co-housing disguised the multiple inequalities within. Environmental factors, from large scale delays to the asylum seeker centre being ready for habitation to very small physical changes, like locking a shared entrance, had major repercussions on contact and atmosphere. In Augsburg, the Grandhotel was developed particularly with an eye to the affectual element of familiarization, where passers-by were encouraged to just walk into a physically open semi-public space. Nevertheless, the contribution shows that entering an asylum centre was still a difficult threshold for some nearby residents to overcome (see also Oliver et al. 2019 on neighbourhood reactions to the new centre).

\section{Concluding discussion}

Using six empirical studies of emerging multi-sector alliances and reconfigurations of multi-level governance, the special issue invites reflection on the extent to which innovation is possible in asylum seeker and refugee reception in European cities. Innovation requires the creation, adoption and spread of new ideas, and the instigation of qualitative change (Sørensen and Torfing 2011). What do these examples tell us about the extent for incremental (or indeed more radical) change in the field of asylum seeker reception?

The collection exemplifies that at local level, a strong desire to develop more adequate approaches to asylum seeker and refugee reception can be frustrated. The policy space available for cities to innovate in this arena remains limited, given constraints of capacity, (legal) competence and funding. There are risks too, both perceived and actual, in striking out outside of national government policies in a highly charged policy area. However, there are also risks in not acting, and cities have emerged as a frontline in identifying new approaches to reception. These approaches speak to wider city issues of inclusion, cohesion and place-making and shaping, and move beyond narrower framings of reception pertaining only to national centralised systems for asylum reception based primarily on legal and governmental frameworks. 
Key in shifting some of these dynamics are multi-sector alliances between local governments, NGOs and a range of non-state actors, as well as city networks. These facilitate conditions for innovation, both practically (through funding opportunities and the sharing of best practice between cities) but also conceptually, by providing cities with the opportunities to define their own policy framing and rationale for action. Change might be rather incremental and indirect, for example through improving conditions that might lead to further opportunities to innovate, as shown in the case study of Barcelona (Garcés-Mascareñas and Gebhardt 2020). Yet as Broadhead (2020) shows, shaping new policy frames is still an important move in creating better conditions and policy space for further action. Crucially however, some of the contributions also show that challenges to the status quo are not easily or cooperatively achieved in this field. Conflict might more readily describe interactions in both multi-level and multi-sector arrangements as new arrangements are struck and competencies fought over (Campomori and Ambrosini 2020; Garcés-Mascareñas and Gebhardt 2020).

The contributions on the practical experiments by Mahieu and van Caudenberg (2020) Oliver et al. (2020) and Zill et al. (2020) show that innovations rely on building local alliances and, a 'turn to the local'. Not only is this through bringing together coalitions of actors with their own particular expertise, but by engaging communities in the sites and localities where asylum seekers are placed. Zill et al. (2020) point out the risk that contact initiatives are presented as some distanced 'utopia', whereas all the examples show that transforming relations at the local level is a complex and concrete process. Despite the attractiveness of the idea, bringing asylum seekers together with locals does not automatically lead to harmony and disruptions to categories of 'us' and 'them'. The contributions show careful attention needs to be paid to the dynamics and inbuilt inequalities between groups, the influence of external conditions (including the effects of national asylum regimes) and the effects of physical environments. The scholarship on these innovations point to the value and importance of learning from such initiatives. Yet the studies also implicitly indicate difficulties in ensuring traction and capitalising on the lessons learned. This may because they are funded only temporarily, and even those that endure, such as the Grandhotel Cosmopolis, are still at risk through their representation in national media as 'special' and unique; as Zill et al. (2020, this issue) argue, these utopian framings dilute their potential for large-scale and serious critique of national approaches.

We end therefore with a call for a continued critical focus of research in charting the potentials within this rapidly shifting territory. Methods to assess the outcomes of such innovations include evaluative approaches which recognise the complexity of attempting change in this field, and which adequately acknowledge as a key part of the story, the wide-ranging influences and contexts which inform such interventions. Sharing learning from innovations in governance and practice is vital, showing that alternatives to more typical national approaches are possible. We simultaneously urge researchers to remain critical. Innovation in asylum seeker reception seems a worthy and important pursuit, but we must avoid overly celebratory and descriptive accounts, in which innovation is unilaterally regarded as leading to better experiences and outcomes for refugees and asylum seekers. A focus on innovation cannot assume that the local level is somehow more progressive, and its innovations, automatically good (Agustín and Jørgensen 2019). This special issue instead seeks to offer a thorough and critical exploration of how alternative policies and practices of asylum seeker reception have emerged at the local level in Europe, and how they are experienced by those that they engage. 


\section{Acknowledgements}

This special issue came out of a series of papers presented at a panel on 'Local innovation in asylum-seeker and refugee reception at the IMISCOE conference in Barcelona 2018. The authors would like to thank the editors of Comparative Migration Studies, and the anonymous reviewers of the papers, who have helped to shape this edition of the journal.

\section{Authors' contributions}

All authors contributed to the article and read and approved the final manuscript.

\section{Funding}

Not applicable.

\section{Availability of data and materials}

Not applicable.

\section{Competing interests}

The authors declare that they have no competing interests.

\section{Author details}

${ }^{1}$ Institute of Education, University College London, 20 Bedford Way, Bloomsbury, WC1H OAL, London, UK. ${ }^{2}$ School of Governance, Utrecht University, Utrecht, Netherlands. ${ }^{3}$ Centre on Migration, Policy \& Society, University of Oxford, Oxford, UK.

Received: 8 June 2020 Accepted: 24 June 2020

Published online: 10 September 2020

\section{References}

Agustín, Ó. G., \& Jørgensen, M. B. (2019). Solidarity cities and cosmopolitanism from below: Barcelona as a Refugee City. Social Inclusion, 7(2), 198-207.

Allport, G. W. (1954). The nature of prejudice. Reading: Addison-Wesley.

Ambrosini, M. (2013). 'We are against a multi-ethnic society': Policies of exclusion at the urban level in Italy. Ethnic and Racial Studies, 36(1), 136-155.

Bakker, L., Dagevos, J., \& Engbersen, G. (2014). The importance of resources and security in the socio-economic integration of refugees. A study on the impact of length of stay in asylum accommodation and residence status on socio-economic integration for the four largest refugee groups in the Netherlands. Journal of International Migration and Integration, 15(3), $431-448$.

Barber, B. (2013). If mayors ruled the world: Dysfunctional nations, rising cities. New Haven: Yale University Press.

Bloch, A. (2008). Refugees in the UK labour market: The contention between economic integration and policy-led labour market restriction. Journal of Social Policy, 37(1), 21-36.

Bock, J.-J. (2018). Migrants in the mountains: Shifting Borders and contested crisis experiences in rural Germany. Sociology, 52(3), 569-586.

Boswell, C. (2008). Evasion, reinterpretation and decoupling: European Commission responses to the 'external dimension' of immigration and asylum. West European Politics, 31(3), 491-512.

Broadhead, J. (2020). Building inclusive cities: Reflections from a knowledge exchange on the inclusion of newcomers by UK local authorities. Comparative Migration Studies, 8. https://doi.org/10.1186/s40878-020-0172-0.

Çağlar, A., \& Glick Schiller, N. (2018). Migrants and City-making: Dispossession, displacement, and urban regeneration. Durham and London: Duke University Press.

Campomori, F., \& Ambrosini, M. (2020). Beyond multilevel governance: The implementation of asylum seekers' reception in Italy as a battleground. Comparative Migration Studies, 8. https://doi.org/10.1186/s40878-020-00178-1.

Caponio, T. (2019). If mayors ruled migration: Promises and gaps. In Migration Policy Centre blog. https://blogs.eui.eu/ migrationpolicycentre/mayors-ruled-migration-promises-gaps/. Accessed 31 May 2020

Caponio, T., \& Borkert, M. (2010). The local dimension of migration policymaking. Amsterdam: Amsterdam University Press, IMISCOE Reports.

Darling, J. (2014). Asylum and the post-political: domopolitics, depoliticisation and acts of citizenship. Antipode, 46(1), 72-91

Darling, J. (2016). Privatising asylum: Neoliberalisation, depoliticisation and the governance of forced migration. Transactions of the Institute of British Geographers, 41(3), 230-243.

De Vroome, T., \& van Tubergen, F. (2010). The employment experience of refugees in the Netherlands. International Migration Review., 44(2), 376-403. https://doi.org/10.1111/j.1747-7379.2010.00810.x.

Dekker, R., Emilsson, H., Krieger, B., \& Scholten, P. (2015). A local dimension of integration policies? A comparative study of Berlin, Malmö, and Rotterdam. International Migration Review, 49(3), 633-658.

Emilsson, H. (2015). A national turn of local integration policy: Multi-level governance dynamics in Denmark and Sweden. Comparative Migration Studies, 3. https://doi.org/10.1186/s40878-015-0008-5.

Eurostat (2020). News Release 48/2020-20 March 2020. https://ec.europa.eu/eurostat/documents/2995521/10554400/3-20032 020-AP-EN.pdf/6ee052a9-ffb8-d170-e994-9d5107def1a8. Accessed 18 May 2020

Garcés-Mascareñas, B., \& Gebhardt, D. (2020). Barcelona: Municipalist policy entrepreneurship in a centralist refugee reception system. Comparative Migration Studies, 8. https://doi.org/10.1186/s40878-020-0173-z.

Geuijen, K., Moore, M., Cederquist, A., Ronning, R., \& Van Twist, M. (2017). Creating public value in global wicked problems. Public Management Review, 19(5), 621-639.

Geuijen, K., Oliver, C., \& Dekker, R. (2020). Local innovation in the reception of asylum seekers in the Netherlands: Plan Einstein as an example of multi-level and multi-sector collaboration. In B. Glorius, \& J. Doomernik (Eds.), Geographies of asylum in Europe and the role of European localities (pp. 245-260). Cham: IMISCOE Research Series. Springer. 
Glorius, B., \& Doomernik, J. (2020). Introduction. In B. Glorius, \& J. Doomernik (Eds.), Geographies of asylum in Europe and the role of European localities (pp. 1-11). Cham: IMISCOE Research Series. Springer.

Hintjens, H., \& Pouri, A. (2014). Toward cities of safety and sanctuary. Peace Review, 26(2), 218-224. https://doi.org/10.1080/ 10402659.2014 .906889$.

Independent Chief Inspector of Borders and Immigration (ICIBI) (2018). An inspection of the Home Office management of asylum accommodation provision. London: ICIBI. https://assets.publishing.service.gov.uk/government/uploads/system/ uploads/attachment_data/file/757285/ICIBI_An_inspection_of_the_HO_management_of_asylum_accommodation.pdf. Accessed 31 May 2020

Jennings, W., \& Stoker, W. (2016). The bifurcation of politics: Two Englands. The Political Quarterly, 87(3), 372-382.

Katz, B., \& Nowak, J. (2018). The new localism. How cities can thrive in the age of populism. Washington, DC: Brookings Institution Press.

Kone, Z., Ruiz, I., \& Vargas-Silva, C. (2019). Refugees and the UK labour market. Oxford University: COMPAS. https://www. compas.ox.ac.uk/wp-content/uploads/ECONREF-Refugees-and-the-UK-Labour-Market-report.pdf. Accessed 20 May 2020

Kreichauf, R. (2018). From forced migration to forced arrival: the campization of refugee accommodation in European cities. Comparative Migration Studies, 6. https://doi.org/10.1186/s40878-017-0069-8.

Li, S. S., Liddell, B. J., \& Nickerson, A. (2016). The relationship between post-migration stress and psychological disorders in refugees and asylum seekers. Current Psychiatry Reports, 18(9), 82

Mahieu, R., \& Van Caudenberg, R. (2020). Young refugees and locals living under the same roof: Intercultural communal living as a catalyst for refugee integration in European urban communities? Comparative Migration Studies, DOI, 8. https://doi. org/10.1186/s40878-019-0168-9.

Marks, G., \& Hooghe, L. (2004). Multi-level governance. Oxford: Oxford University Press.

Mayblin, L. (2016). What will Brexit mean for asylum in the UK? Open Democracy. https://www.opendemocracy.net/en/whatwill-brexit-mean-for-asylum-in-uk/. Accessed 05 Dec 2019

Mayblin, L., \& James, P. (2019). Asylum and refugee support in the UK: Civil society filling the gaps? Journal of Ethnic and Migration Studies, 45(3), 375-394. https://doi.org/10.1080/1369183X.2018.1466695.

Miller, K. E., \& Rasmussen, A. (2017). The mental health of civilians displaced by armed conflict: An ecological model of refugee distress. Epidemiology and Psychiatric Sciences, 26(2), 129-138.

Oliver, C., Dekker, R., \& Geuijen, K. (2019). The Utrecht refugee Launchpad final evaluation report. Oxford: COMPAS, University of Oxford.

Oliver, C., Geuijen, K., \& Dekker, R. (2020). Conditions of social contact and encounter in asylum seeker reception: The Utrecht refugee Launchpad. Comparative Migration Studies, 8. https://doi.org/10.1186/s40878-020-00187-0.

Oomen, B. (2019a). Cities of refuge: Rights, culture and the creation of cosmopolitan citizenship. In R. Buikema, A. Buyse, \& A. Robben (Eds.), Cultures, citizenship and human rights. London: Routledge.

Oomen, B. (2019b). Decoupling and teaming up: The rise and proliferation of transnational municipal networks in the field of migration. International Migration Review, 1-27. https://doi.org/10.1177/0197918319881118.

Pannizon, M., \& van Riemsdijk, M. (2019). Introduction to the special issue: 'Migration governance' in an era of large movements. A multi-level approach. Journal of Ethnic and Migration Studies, 45(8), 1225-1241. https://doi.org/10.1080/ 1369183X.2018.1441600.

Poppelaars, C., \& Scholten, P. (2008). Two worlds apart: The divergence of national and local immigrant integration policies in the Netherlands. Administration \& Society, 40(4), 335-357.

Rea, A., Martiniello, M., Mazzola, A., \& Meuleman, B. (2019). Introduction. The Refugee Reception Crisis in Europe. Polarized Opinions and Mobilizations. In The Refugee Reception Crisis in Europe: Polarized Opinions and Mobilizations (pp. 11-30). Bruxelles: Editions de l'Université de Bruxelles.

Sassen, S. (2012). When the center no longer holds: Cities as frontier zones. Cities, 34, 67-70.

Scholten, P. (2013). Agenda dynamics and the multi-level governance of intractable policy controversies: The case of migrant integration policies in the Netherlands. Policy Sciences, 46, 217-236.

Scholten, P., \& Penninx, R. (2016). The multilevel governance of migration and integration. In B. Garcés-Mascareñas, \& R. Penninx (Eds.), Integration Processes and Policies in Europe. Context, Levels and Actors, IMISCOE research series (pp. 91-108). London: Springer Open.

Slominski, P., \& Trauner, F. (2018). How do member states return unwanted migrants? The strategic (non-)use of 'Europe' during the migration crisis. Journal of Common Market Studies, 56, 101-118.

Sørensen, E., \& Torfing, J. (2011). Enhancing collaborative innovation in the public sector. Administration \& Society, 43(8), 842-868.

Spencer, S. (2018). Multi-level governance of an intractable policy problem: Migrants with irregular status in Europe. Journal of Ethnic and Migration Studies, 44(12), 2034-2052. https://doi.org/10.1080/1369183X.2017.1341708.

Whyte, Z., Larsen, B. R., \& Fog Olwig, K. (2019). neighbours in a time of change: local pragmatics and the perception of asylum centres in rural Denmark. Journal of Ethnic and Migration Studies, 45(11), 1953-1969. https://doi.org/10.1080/ 1369183X.2018.1482741

Zapata-Barrero, R. (2019). Guest editorial: Methodological interculturalism: Breaking down epistemological barriers around diversity management. Ethnic and Racial Studies, 42(3), 346-356. https://doi.org/10.1080/01419870.2019.1538527.

Zapata-Barrero, R., Caponio, T., \& Scholten, P. (2017). Introduction. Theorizing the 'local turn' in a multi-level governance framework of analysis: A case study in immigrant policies. International Review of Administrative Sciences, 83(2), 241-246.

Zill, M., Spierings, B., \& Van Liempt, I. (2020). The Grandhotel Cosmopolis - a concrete utopia? Reflections on the mediated and lived geographies of asylum accommodation. Comparative Migration Studies, 8. https://doi.org/10.1186/s40878-020-0171-1.

Zorlu, A. (2017). Attitudes toward asylum seekers in small local communities. International Migration, 55(6), 14-36.

\section{Publisher's Note}

Springer Nature remains neutral with regard to jurisdictional claims in published maps and institutional affiliations. 